\title{
REVIEW ARTICLE \\ A Complete Overview on Profile and Medicinal uses of Punica grantum $l$. (Pomegranate) and its Health Benefits
}

\author{
Kaushik Vilas Kulkarni* \\ Department of Quality Assurance, D.S.T.S Mandal's College of Pharmacy, Jule Solapur, Solapur, India. \\ Manuscript No: IJPRS/V7/I1/00011, Received On: 20/02/2018, Accepted On: 28/02/2018
}

\begin{abstract}
Pomegranate has been used for thousands of years to cure a wide range of diseases across different cultures and civilizations. It has high nutritional values and numerous health benefits. Nowadays, besides its use as a fruit, its medicinal properties have attracted the interest of researchers of many countries. Pomegranate fruit has medicinal properties such as anti-inflammatory and antibacterial activities. The pomegranate seed oil has an inhibitory effect on skin and breast cancers. The pomegranate seed oil has phytoestrogenic compounds, and the fruit is rich in phenolic compounds with potent antioxidant activity. Ellagic acid is one of the leading components of pomegranate with phenolic structure and antioxidant activity. The dried bark of the stem and roots has long been used as an anthelmintic. Pomegranate peel/rind combined with opium and an aromatic, like cloves may be a useful drug in chronic diarrhea and dysentery. The dried root is employed as an abortifacient. Extracts of the rinds have been shown to be bactericidal, antiviral, anti-tumor and use of pomegranates in the treatment of Acquired Immune Deficiency Syndrome (AIDS) owing to their antioxidant properties and botanical uniqueness. Pomegranate shows neuroprotective effects against Alzheimer's disease in several reported animal studies. This review article presents the recently published findings on different aspects of this plant focusing on its medicinal properties.
\end{abstract}

\section{KEYWORDS}

Pomegranate (Punica grantum), Phytochemistry, Pharmacological activity, Health benefits, Scientific reports

\section{INTRODUCTION}

Medicinal plants play an essential role in the development of potent therapeutic agents. Natural products from plant, animal, and minerals have been the basis of the treatment of human disease. Today estimate that about $80 \%$ of people in developing countries still relays on traditional medicine mainly based on species of plants and animals for their primary health care.

\footnotetext{
*Address for Correspondence:

Kaushik Vilas Kulkarni,

Department of Quality Assurance,

D.S.T.S Mandal's College of Pharmacy, Jule Solapur, Solapur, India.

E mail ID: Kaushik.kulkarni3518@gmail.com
}

Herbal medicines are currently in demand, and their popularity is increasing day by day.

About 500 plants with medicinal use are mentioned in ancient literature, and around 800 plants have been used in indigenous system of medicine. India is a vast repository of medicinal plants that are used in traditional medical treatments. In India are around 20,000 medicinal plant species have been recorded recently but more than 500 classic communities used about 800 plant species for curing disease. Currently, $80 \%$ of the world population depends on plant-derived medicines for the first line of primary health care for human 
alleviation because it has no side effects. Plants are important sources of drugs, and presently about $25 \%$ of pharmaceutical prescriptions in the United States contain at least one plantderived ingredient ${ }^{1}$. The attempt is made to present a complete overview of the plant Punica granted. The Latin word pomum "apple" and granatus "seeded" is the source of name pomegranate. Punica granutam is popularly known as pomegranate (Anar). It is a member of Punicaceae family, which is a large deciduous shrub or small tree native to Asia ${ }^{2}$. Pomegranate was domesticated in $2000 \mathrm{BC}$ and was one of the first five fruit crops (date palm, fig, olive, grape, and pomegranate) to be domesticated by mankind. The usage of pomegranate is deeply embedded in human history with references in many ancient cultures for its use as food and medicine. India is one of the largest producers of pomegranate in the world. During 2013-14, the pomegranate was cultivated over 1.31 lakh ha with an annual production of 13.46 lakh tonnes and productivity of 10.27 tonnes / ha in India. At present, Maharashtra is the leading state in acreage covering about 68.7 percent of the area under pomegranate. Similarly, around 70.2 percent of total production comes from Maharashtra. The other essential states next to Maharashtra with respect to pomegranate cultivation are Karnataka, Gujarat and Andhra Pradesh. India is the only country in the world where pomegranate is available throughout the year (January - December). At the global level, India is the world's largest producer of pomegranates, followed by Iran.

Pomegranate has extensively been used as a source of traditional medicine. ${ }^{3,4}$ Pomegranate fruit has medicinal properties such as antiinflammatory and antibacterial activities. The pomegranate seed oil has an inhibitory effect on skin and breast cancers. The pomegranate seed oil has phytoestrogenic compounds, and the fruit is rich in phenolic compounds with potent antioxidant activity. The fruit and bark of pomegranate are used against intestinal parasites, dysentery, and diarrhea. The juice and seeds are considered a tonic for throat and heart. It is used to stop nose and gum bleeds and treating hemorrhoids. ${ }^{5}$ Punica granutam have been used in folk medicine for centuries in the Middle East, India, and China, and it has been used to treat ailments ranging from inflammation and rheumatism to the pain of a simple sore throat. The most famous usage worldwide has been as a vermifugal or taenicidal agent ${ }^{6,7}$

\section{Taxonomical Classification}

The taxonomic classification of Punica granatum is as follows:

Kingdom: Plantae

Botanical name: Punica granatum

Division: Magnoliophyta

Class: Magnoliopsida

Order: Myrtales

Family: Punicaceae

Genus: Punica

Specie: granatum

\section{Synonyms $^{8}$}

Granatum punica St Lag, Punica florida Salisb, Punica multiflorida Hort, exSiebold and Voss, Punica nana Linn, Punica spinosa Lam, and Punica grandiflora Hort.exSteud

\section{Vernacular Names ${ }^{9}$}

Hindi: Anar, Dhalim, Dharimb

Marathi: Dalimba

Sanskrit: Bijapura, Dadima, Dadimasara, Dalika

Punjabi: Anar, Dan, Danu

English: Pomogranate

Tamil: Kalumal madalai, Madulam, Madulangam

Types of Anar According To Taste ${ }^{10}$

- Sweet Anar

- Sour Anar

- Combination of both sweet and sour.

Plant Description in Unani Texts 
Anar is fruit of celebrated tree, its plant is cultivated all over in nice continent (Barre Azam) some plants are twenty feet tall, stem thin, dimension three or four feet, barks are some xanthous or dark brown in color, the new leaves are mature within the month of Gregorian calendar month of December and March, its leaves are organized within the front of branches. Some are elongated whereas others are xanthous red; the red flowers are organized two in one place, the fruits return when shedding of flowers. The diameter of pomegranate is roughly 3.5 inch; some are terribly huge as narrated in Tazke Jahangeri that one dropped at Emperor Jahangir weighed was forty tola $(400 \mathrm{~g})$. The seed of the pomegranate, some are red, elongated whereas others are white. Generally seeded, some are seedless or week seed; Kabuli pomegranate is taken into account best in quality compared of a different country. Patna pomegranate best is that the quality that has big seed.

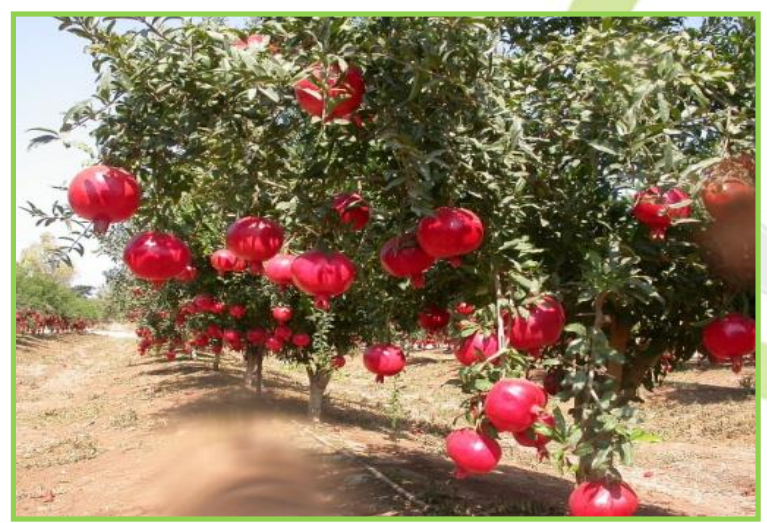

Figure 1: Pomegranate tree

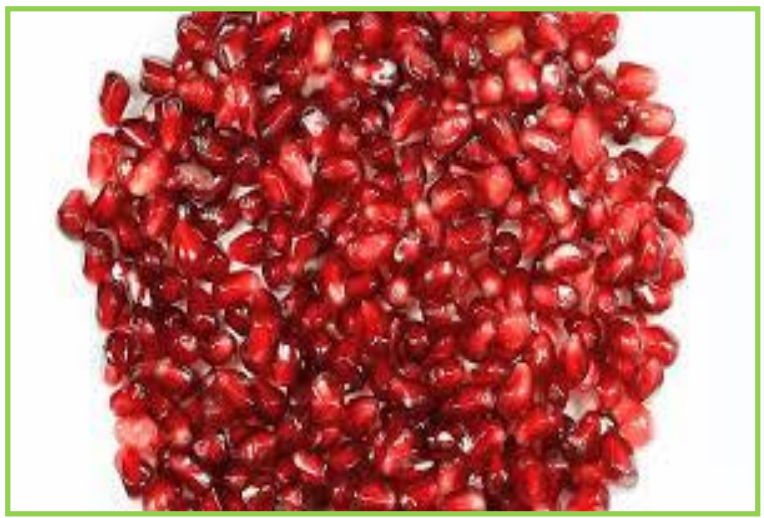

Figure 2: Seeds of pomegranate

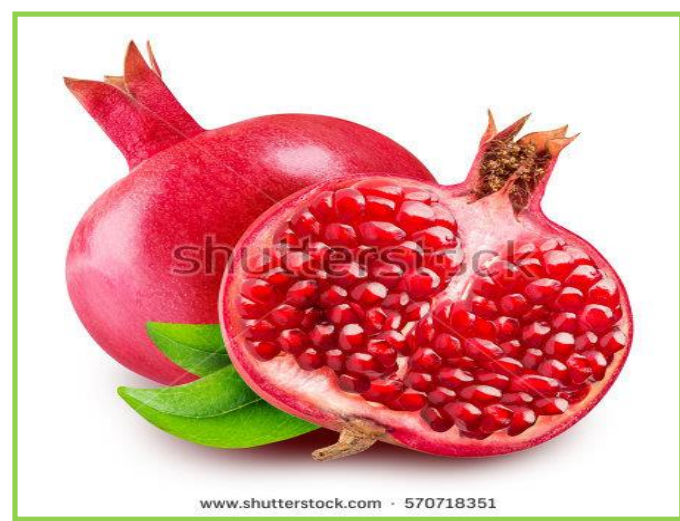

Figure 3: Pomegranate fruit

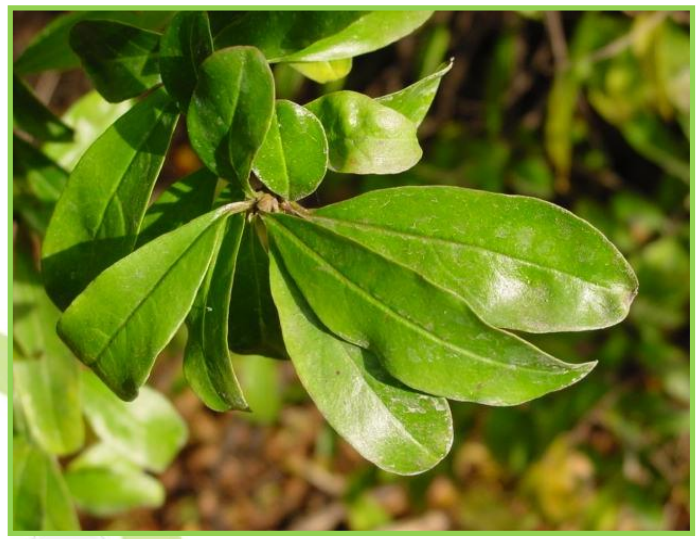

Figure 4: Leaves of pomegranate
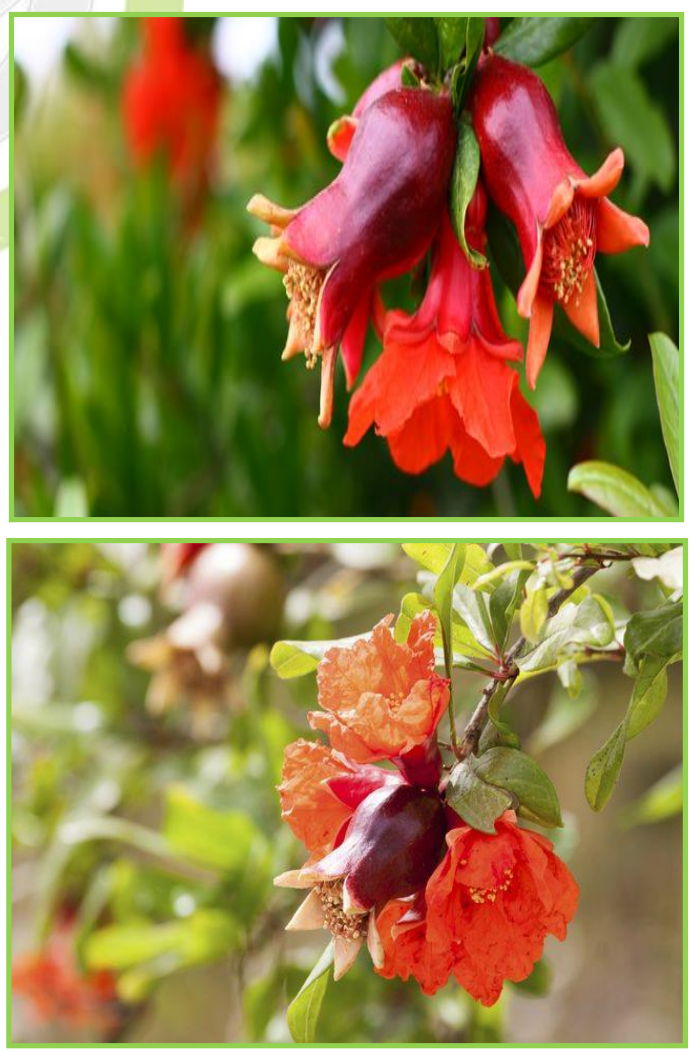

Figure 5: Flowers of pomegranate 


\section{Phytochemistry}

Table 1: List the principle constituents of the Punica grantum tree and fruit ${ }^{11}$

\begin{tabular}{|l|l|}
\hline Plant components & Constituents \\
\hline Pomegranate juice & $\begin{array}{l}\text { Anthocyanins, glucose, ascorbic acid, ellagic acid, gallic acid, } \\
\text { caffeic acid, catechin, quercetin, rutin and numerous minerals } \\
\text { particularly iron, amino acids. }\end{array}$ \\
\hline Pomegranate seed oil & $\begin{array}{l}\text { 95 - Percent punicic acid, other constituents including ellagic acid } \\
\text { other fatty acids, sterols. }\end{array}$ \\
\hline Pomegranate pericarp & $\begin{array}{l}\text { Phenolic punicalagins; gallic acid, and other fatty acids; catechin, } \\
\text { quercetin, rutin and other flavonols, flavones, flavanones, } \\
\text { anthocyanidins. }\end{array}$ \\
\hline Pomegranate leaves & $\begin{array}{l}\text { Tannins (punicalin and punicafolin) and flavones glycosides } \\
\text { including luteolin and apigenin. }\end{array}$ \\
\hline Pomegranate flower & $\begin{array}{l}\text { Gallic acid, ursolic acid, triterpenoids, including maslinic and } \\
\text { asistic acid and other unidentified condtituents. }\end{array}$ \\
\hline $\begin{array}{l}\text { Pomegranate roots and } \\
\text { bark }\end{array}$ & $\begin{array}{l}\text { Numerous piperidine alkaloids ellagitannis, including punicalin and } \\
\text { punicalagin. }\end{array}$ \\
\hline
\end{tabular}

Table 2: Nutritional Value of Punica Grantaum (per $100 \mathrm{Gm}$ edible portions) $^{12}$

\begin{tabular}{|c|c|c|}
\hline Sr. no. & Contents & GM or mg \\
\hline 1 & Carbohydrates & $17.17 \mathrm{gm}$ \\
\hline 2 & Sugars & $16.57 \mathrm{gm}$ \\
\hline 3 & Dietary Fiber & $0.6 \mathrm{gm}$ \\
\hline 4 & Fat & $0.3 \mathrm{gm}$ \\
\hline 5 & Proteins & $0.95 \mathrm{gm}$ \\
\hline 6 & Vitamins & $7.254 \mathrm{mg}$ \\
\hline 7 & $\begin{array}{c}\text { Thiamin (Vit } \\
\text { B1) }\end{array}$ & $0.030 \mathrm{mg}$ \\
\hline 8 & $\begin{array}{c}\text { Riboflavin } \\
\text { (Vit B2) }\end{array}$ & $0.063 \mathrm{mg}$ \\
\hline
\end{tabular}

\begin{tabular}{|c|c|c|}
\hline 9 & $\begin{array}{c}\text { Niacin(Vit } \\
\text { B3) }\end{array}$ & $0.30 \mathrm{mg}$ \\
\hline 10 & $\begin{array}{c}\text { Pantothenic } \\
\text { acid ( B5) }\end{array}$ & $0.596 \mathrm{mg}$ \\
\hline 11 & Vitamin B6 & $0.105 \mathrm{mg}$ \\
\hline 12 & $\begin{array}{c}\text { Folate(Vit } \\
\text { B9) }\end{array}$ & $0.06 \mathrm{mg}$ \\
\hline 13 & Vitamin & $6.1 \mathrm{mg}$ \\
\hline 14 & Minerals & $273.42 \mathrm{mg}$ \\
\hline 15 & Calcium & $3 \mathrm{mg}$ \\
\hline 16 & Iron & $0.30 \mathrm{mg}$ \\
\hline 17 & Magnesium & $3 \mathrm{mg}$ \\
\hline 18 & Phosphorous & $8 \mathrm{mg}$ \\
\hline
\end{tabular}


A Complete Overview on Profile and Medicinal uses of Punica grantum I. (Pomegranate) and its Health Benefits

\begin{tabular}{|c|c|c|}
\hline 19 & Potassium & $259 \mathrm{mg}$ \\
\hline 20 & Zinc & $0.12 \mathrm{mg}$ \\
\hline 21 & Oxalic acids & $14 \mathrm{mg}$ \\
\hline 22 & Nicotinic acid & $0.3 \mathrm{mg}$ \\
\hline
\end{tabular}

Calorific value $=70 \mathrm{k} \mathrm{cal} / 100 \mathrm{gms}$

Table 3: Phytoconstituents of Punica grantum

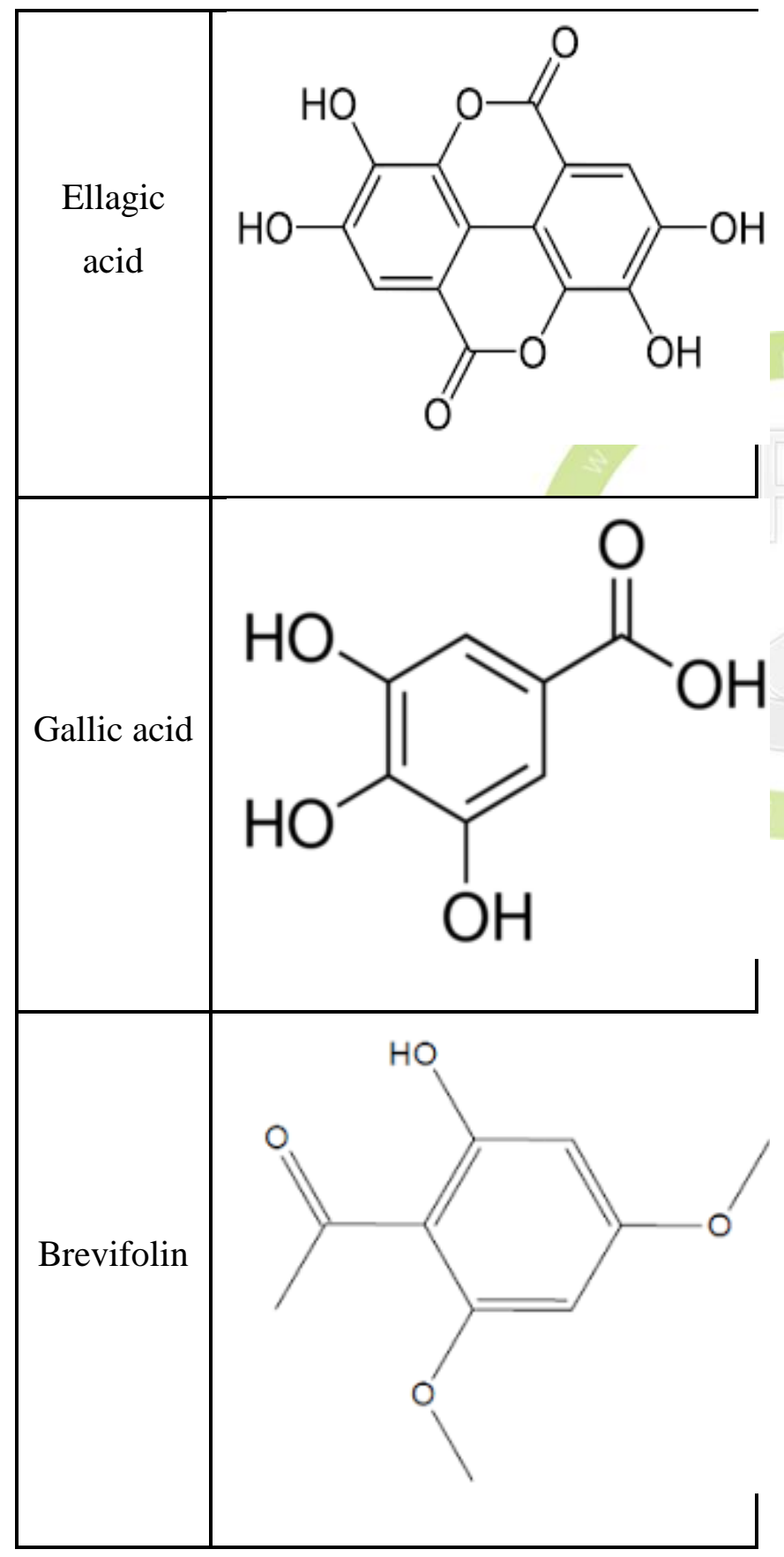

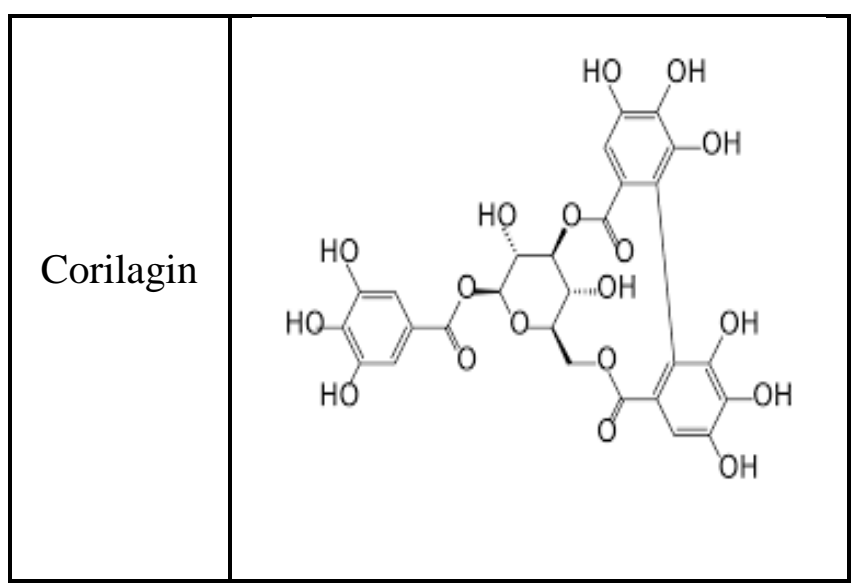

\section{Pharmacological Actions}

The plant has been described to have various pharmacological activities such as vermifuge, antiulcer, cardiotonic, aphrodisiac, amenogoguage, nematicide, parasiticide, appetizer, laxative, diuretic, digestive ${ }^{13}$, anodyne, astringent, bactericidal, stimulant, stomachic, styptic $^{14}$ antispasmodic, antihelmintic, analgesic, abortifacient, amebicide anti-aging, antiatherogenic, antifertility and anti tubercular ${ }^{15}$. It has been traditionally used in conditions like abortion, anorexia, asthma, biliousness, dysmenorrhoea, dyspepsia, epistaxis, hemorrhoids, high cholesterol, fever, bronchitis, brain disease, chest problems, scabies and kidney disorder, haematuria, impotence, inflammation ${ }^{16}$, bleeding, burn, cholera ${ }^{17}$, cough, dermatosis, diabetes, diarrhea, dysentery ${ }^{18}$, infection, infertility, cough, cardiac problems, metrorrhagia, leucorrhoea and leprosy ${ }^{19}$.

\section{Advantages and Therapeutic Uses of Various Parts of Pomegranate (Anar) ${ }^{20}$}

\section{Bark}

The dried bark of the stem and roots has long been used as an anthelmintic. The bark and fruit combined with other drugs are prescribed for the treatment of snake bite. The bark is also prescribed for scorpion bite. Stewing of the bark once taken orally followed by a purgative medicine acts as an anthelmintic. Stewing of root bark is used for tapeworm. In India hot water extract of dried bark and fruit is taken orally for Hansen's disease, leucorrhoea, and menorrhagia and as an anthelmintic. 


\section{Rind}

Pomegranate peel/rind combined with opium and an aromatic, like cloves may be a useful drug in chronic diarrhea and dysentery. A decoction of peel is advised in abdominal ache and within the infectious disease whereas infusion of the same material is taken for inflammatory bowel disease. Associate in a nursing infusion of fine fruit, rind and rice flour is used in looseness of the bowels and dysenteries, as an anthelmintic. An infusion of the rind and root was used by the early colonist as an injection of leucorrhoea. In European nation, hot water extract of edible fruit peel is used for inflammation. In North American nation hot water extract of fruit peel is taken orally to prevent excessive hemorrhage throughout menstruation. In gulf, edible fruit peel is used as a contraceptive in the form of pessary for birth control. In Asian nation poultice of fruits peel and genus, Tamarix gallica bark is applied double in twenty-four hours to the breast to abate flabbiness water extract of edible fruit peel is taken orally for treating looseness of the bowels and infectious disease.

\section{Flowers}

Fine flower powder used for a respiratory disorder. Infusion of flower used as vermifuge. Stewing of flowers used as a gargle for throat inflammation. Flower used as a remedy for cut wounds, bronchitis, looseness of the bowels and system.

\section{Leaves}

Stewing of tender leaves are used as a gargle for buccal affliction. In Asian nation plight extract of leaves is taken orally for irregular menstruation. In Brazil plight extract of dried leaves is used outwardly for ladies issues. In African country leaves crushed in water are taken orally to expel tapeworm.

\section{Roots}

Dried root is employed as an abortifacient. Three-part Allium cepa seeds, three-part of Punica granatum. Two part of Cajanus cajan and red lead oxide are taken with honey orally.
In Republic of Peru plight extract of dried root are taken orally for abortion, as an associate in nursing antidiarrhoeal and for the bloody infectious disease.

\section{Fruits}

Hot water extract of dried fruit is employed outwardly for wounds, ulcer, bruise sore, mouth lesion, stomatitis, leucorrhoea, and vaginitis. In African country extract of dried fruit is employed for a skin lesion. In Asian nation extract of dried fruit is taken orally by pregnant ladies for kid birth disorder. In the Asian nation, fine immature fruit is taken orally for peptic ulcer. Olive oil extract of dried fruit is employed outwardly to forestall premature graying of hair. The mixture contains Terminalia arjuna, Aglaia Roxburghiana, Jasminum Officinalis, Indigofera tinctoria, Tinospora cordifolia, Pterocarpus marsupium, Eclipta Alba, Pandanus tectorius, Oroxylum indicum, Valeriana harchivik, Terminalia chebula, Terminalia belerica, Emblica Officinalis , Punica granatum , and Sesamum indicum.

\section{Whole Plants}

Fresh entire plant created into past is used for snake bite. The paste is applied to the bite site. Juice is dropped into the nostrils ears and navel.

\section{Clinical Applications of Pomegranate}

Pomegranates are biologically unique and potent source of many of the body's physiological factors having significant effects on human health. Pomegranate fruit has been recommended as a pharmaceutical and food ingredient in the treatment of acquired immune deficiency syndrome (HIV/AIDS) due to the enrichment of divers bioflavonoids, inhibition of free radicals, as well as lipooxygenases inhibition (the enzymes that transform arachidonic acid to leukotrienes). ${ }^{21}$ The pomegranate peels have traditionally used to treat ordinary diarrhea and dysentery. The focus of future studies is concentrated on producing natural antidiarrhea remedy from pomegranate peel for over-the-counter, or prescription-based medications. ${ }^{22}$ Pomegranate is identified as an 
antiparasitic fruit for both humans and livestock. $^{22}$ Flavonoids contained in the fruit not only have powerful antioxidant activity but they also have inhibitory effects on enzymes since the juice and oil behave as potential nutritional supplement in enhancing longevity as well as preventing from heart disease and cancer. ${ }^{23}$ The extracted oil of pomegranate can effectively prohibit the production of prostaglandin or leukotriene through inhibition of cycloxygenase and lipoxygenase eicosanoid enzymes so that it may increase the application of oil or its derivatives as internal or external anti-inflammatory substances. ${ }^{23}$ The recent focus on the use of phytoestrogenic compounds in medicine for the prevention and treatment of menopause, osteoporosis, and cardiovascular diseases induced by reduced estrogen and cancer may possibly increase the prospect of using pomegranate seed oil and juice for postmenopausal women to be replaced by internal and external phytoestrogen as an alternative to hormone replacement therapy (HRT).

\section{Scientific Reports on Health Benefits of Pomegranate}

\section{Hypoglycaemic Activity}

Dhavan B et al. reported the hypoglycaemic activity of Ethanol /water (1:1) extract of aerial parts, administered orally to rats at a dose of $250.0 \mathrm{mg} / \mathrm{kg}$, was inactive. Less than $30 \%$ drop in blood sugar level was observed ${ }^{15}$.

\section{Immunomodulatory Activity}

A study was carried out to investigate the immunomodulatory activity of Anar by Ross G et al. that aqueous suspension of fruit rind powder, administered orally to rabbits at a dose of $100 \mathrm{mg} / \mathrm{kg}$, stimulated the cell-mediated and humoral components of the immune system. There was an increase in antibody titre to typhoid-H antigen.

\section{Analgesic Activity}

A study was carried out to confirm the analgesic activity by Dhavan B. et al. that Ethanol /water (1:1) extract of aerial parts, administered intraperitoneally to mice at a dose of $0.125 \mathrm{mg} / \mathrm{kg}$, was active vs. tail pressure method. ${ }^{15}$

\section{Anticonvulsant Activity}

Another study was carried out by Dhavan B. et al. to found out the anticonvulsant activity in Anar that Ethanol/water extract (1:1) extract of aerial parts, administered intraperitoneally to mice at a dose of $0.125 \mathrm{mg} / \mathrm{kg}$ was inactive vs. electroshock-induced convulsions. ${ }^{15}$

\section{Anthelmintic Activity}

Antihelmintic activity of Punica granatum was studied by Singhal KC, he reported that the chloroform extract of dried root and stem, administered to mice by gastric intubation at a dose of $250.0 \mathrm{mg} / \mathrm{kg}$ for 3 days, was active on Hymenolepsis nana and inactive on Nippostrongylus brasiliense and syphacia obvelata. $^{24}$

\section{Anti fertility Activity}

Gujraj M, Varma DR, and Sareen KN. observed anti fertility effect in fruit peel, in the ration of guinea pig of both sex at a dose of $18.0 \mathrm{~g} / \mathrm{kg}$ and in the ration of female rats, was active. ${ }^{25}$

\section{Antifungal Activity}

Dhavan B. et al. reported the antifungal activity of Punica granatum in Ethanol/water (1:1) extract of aerial parts, at a concentration greater than $25.0 \mathrm{mcg} / \mathrm{ml}$ on an agar plate, was inactive on Microsporum Canis, Trichophyton menta geophytes, and Aspergillus nigar ${ }^{15}$. Anesini C. and Perez. also revealed that hot water extraction dried entire plant at a concentration $62.02 \mathrm{mg} / \mathrm{ml}$ on an agar plate was active on Aspergillus niger. ${ }^{26}$

\section{Anti diabetic Effect}

A study was carried out to investigate the anti diabetic effect in flowers by Jafri MA. et al. They revealed that ethanol extract of the abortive male flowers, administered orally to normal glucose fed hyperglycaemic, and alloxan induced diabetic rats, produced significant blood glucose lowering effect. ${ }^{27}$ 


\section{Anti-inflammatory Activity}

A study was carried out to confirm the antiinflammatory activity by Mascolo $\mathrm{N}$ et al. The results of study revealed that ethanol (80\%) extract of dried fruit peel, administered by gastric intubation to male rats at a dose of 100.0 $\mathrm{mg} / \mathrm{kg}$, produced weak activity vs. carrageenininduced pedal edema. twenty-three percent inhibition of edema was observed. ${ }^{28}$

\section{Gastro Protective Activity}

A study was carried out by Gharzouli $\mathrm{K}$ et al. that aqueous extract of the fruit peel experimented in the animal model against ethanol-induced damage the rat against. The extract produced $100 \%$ precipitation of ovine hemoglobin in vitro. Oral administration induced a significant decrease in the gastric lesion. The protection was more significant when the test drug was given at the same time. ${ }^{29}$

\section{Uterine Stimulant Effect}

A study was carried out by Dhawan BN \& Sexena PN that water extract of fruit peel was active in the uterus of nonpregnant rats. ${ }^{30}$

\section{Cytotoxic Activity}

Sato A reported that the Punica granatum have cytotoxic potential. He concluded that the hot water extract of fruit peel, at a dose of 120.0 $\mathrm{mcg} / \mathrm{ml}$ in cell culture, was active on CA-JTC26. The inhibition rate was $59 \% .^{31}$

\section{Anticarcinogenic Activity}

In vitro assays utilizing three prostate cancer cell lines (DU-145, LNCaP, and PC-3) demonstrated various pomegranate extracts (juice, seed oil, peel) potently inhibit prostate cancer cell invasiveness and proliferation, cause cell cycle disruption, induce apoptosis, and inhibit tumor growth. These studies also demonstrated combinations of pomegranate extracts from different parts of the fruit were more effective than any single extract. ${ }^{32,33}$ Several animal studies have elucidated pomegranate's potential anticancer mechanisms. Two studies in mice implanted with the prostate cancer PC-3 cell line demonstrated pomegranate fruit extract (PFE; edible parts of the fruit, excluding the peel) inhibits cell growth and induces apoptosis via modulation of proteins regulating apoptosis. ${ }^{34,35}$

\section{Pomegranate's Neuroprotective Effects against Alzheimer's Disease}

Pomegranate shows neuroprotective effects against Alzheimer's disease in several reported animal studies. However, whether its constituent ellagitannins and their physiologically relevant gut microbiota-derived metabolites, namely urolithins $(6 \mathrm{H}$ dibenzo $[\mathrm{b}$, d] pyran-6-one derivatives), are the responsible bioactive constituents is unknown. Therefore, from a pomegranate extract, previously reported by our group to have anti- Alzheimer's disease effects in vivo, 21 constituents, which were primarily ellagitannins, ware isolated and identified (by HPLC, NMR, and HRESIMS) is silico computational studies, used to predict blood-brain barrier permeability. Therefore, urolithins are the possible brain absorbable compounds which contribute to pomegranate's anti-Alzheimer's effects warranting future in vivo studies on these compounds.

\section{CONCLUSION}

Pomegranate fruit has been part of Indian diet for a very long time. It was used in Ayurvedic medicine as the healing food. An article shows strongly present detailed information about the plant pomegranate and different biologically active compounds. The discovery that plants generate hormonally active phytochemicals has altered our understanding of the connection between diet and human health. Antioxidant activity of pomegranate fruit has been attributed to the presence of some components like ascorbic acid and phenolic compounds, including punicalagin, punicalin, gallic acid, ellagic acid, and anthocyanins. Punica granatum has been claimed in traditional literature to be valuable against a wide variety of diseases, such as anorexia, asthma, biliousness, dysmenorrhoea, dyspepsia, epistaxis, hemorrhoids, high cholesterol, fever, bronchitis, brain disease, chest problems, scabies and kidney disorder, haematuria, impotence, inflammation, bleeding, burn, cholera, cough, 
dermatosis, diabetes, diarrhea, dysentery, infection, infertility, cough, cardiac problems, metrorrhagia, leucorrhoea and leprosy. Pomegranate plant used in traditional medicine for many years and the reported phytochemical and pharmacological studies supported its traditional uses and proved to be useful for clinical studies and development of the commercial drug. According to the UN agency, this medicative plant is that the best supply to get the style of medication. Concerning eightieth of people from developed countries use them ancient medicines. Pomegranate juice and extract are used extensively within the people medication of ancient cultures for varied medicative properties. This review aims to spotlight the medicative importance of the plant Punica grantum.

\section{REFERENCES}

1. Garach, D., Pake, A., Chakraborty, M., \& Kamath, J. V. (2012). Phytochemical and pharmacological profile of Punica granatum: an overview. International Research Journal of Pharmacy, 3(2): 65-68.

2. Das, A. K., Mandal, S. C., Banerjee, S. K., Sinha, S., Das, J., \& Pal, M. (1999). Studies on antidiarrhoeal activity of Punica granatum seed extract in rats. Journal of Ethnopharmacology, 68(1-3), 205-208.

3. Al-Said, F. A., Opara, L. U., \& Al-Yahyai, R. A. (2009). Physical, chemical and textural quality attributes of pomegranate cultivars (Punica granatum L.) cultivars in Eastern Mediterranean region of Turkey. African Journal of Biotechnology, 7, 1294-1301.

4. Akbarpour, V., Hemmati, K., \& Sharifani, M. (2009). Physical and chemical properties of pomegranate (Punica granatum L.) fruit in maturation stage. American-Eurasian Journal of Agriculture and Environmental Sciences, 6(4), 411-416.

5. http://articles.mercola.com/sites/articles/arc hive/2014/05/10/pomegranates.aspx. (Accessed feb 15, 2018.)

6. Zhicen, L. (1987). Colour atlas of Chinese traditional drugs. Science Press, Beijing, People's Republic of China, 1: 75-76.

7. Kapoor, L. D. (2000). Handbook of Ayurvedic medicinal plants: Herbal reference library (Vol. 2). CRC press.

8. James, A. D. (2008). Duke's hand book of medicinal plants of the bible. London: CRC press Taylor and Francis group; 242-62.

9. Anonymous. (1948). The wealth of India. PID, CSIR, new Delhi P, 12, 1962.

10. Bently, R. \& Trimen, H. (2004). Medicinal Plants. New Delhi: Asiatic Publishing House Laxmi Nagar, 2: 113.

11. Jurenka, J. (2008). Therapeutic applications of pomegranate (Punica granatum L.): a review. Alternative medicine review, 13(2), 128-144.

12. http://shodhganga.inflibnet.ac.in/bitstream/1 0603/105670/8/08_chapter\%203.pdf (Accessed on 17 feb 2018.)

13. Khare, C. P. (2007). Indian Medicinal Plants an Illustrated dictionary. New Delhi: Rajkamal electric press: 527-528.

14. Anonymous. Medicinal plant in folkore of Bihar and Orissa. New Delhi: CCRUM Ministry of health and Welfare .Govt of India.143-7, 2011.

15. Dhawan, B., Patnaik, K., Rastoghi, R. P., Singh, K. K. \& Tondon, J. S. (1977). Screening of Indian plants for biological activity: Indian Journal of Experimental Biology, 15: 208-19, 1977.

16. Kirtikar, K. R. \& Basu, B. D. (2013). Indian medicinal plants. Vol V. Dehradun. Oriented Enterprises, 1508-1512.

17. Ross, R. G., Selvasubramanian, S., \& Jayasundar, S. (2001). Immunomodulatory activity of Punica granatum in rabbits - a preliminary study. Journal of Ethnopharmacology, 78(1), 85-87.

18. Nadkarni, K. M. (2004). Indian Plants and drugs with their medicinal properties and uses. New Delhi, Srishti book Distributor, 325-327. 
19. Anonymous. Medicinal plant in folkore of Bihar and Orrisa. New Delhi: CCRUM Ministry of health and welfare Govt of India.143-147, 2001.

20. Ross, I. A. (2007). Medicinal plants of the world, volume 3: Chemical constituents, traditional and modern medicinal uses(Vol. 3). Springer Science \& Business Media.

21. Lee, J., \& Watson, R. R. (1998). Pomegranate: a role in health promotion and AIDS. Nutrients and Foods in AIDS, 179192.

22. Hozumi, T., Oyama, H., Shiraki, K.. (1977). Pharmaceutical preparation for the treatment of AIDS. Jpn Kokai Tokkyo Koho, 195.

23. Schubert, S. Y., Lansky, E. P., \& Neeman, I. (1999). Antioxidant and eicosanoid enzyme inhibition properties of pomegranate seed oil and fermented juice flavonoids. Journal of Ethnopharmacology, 66(1), 11-17.

24. Singhal, K. C. (1983). Anthelmintic activity of Punica granatum and Artemisia siversiana against experimental infections in mice. Indian Journal of Pharmacology, 15(2), 119-122.

25. Gujral, M. L., Varma, D. R., \& Sareen, K. N. (1960). Oral contraceptives. Part I. Preliminary observations on the antifertility effect of some indigenous drugs. The Indian Journal of Medical Research, 48, 46-51.

26. Anesini, C., \& Perez, C. (1993). Screening of plants used in Argentine folk medicine for antimicrobial activity. Journal of Ethnopharmacology, 39(2), 119-128.

27. Jafri, M. A., Aslam, M., \& Singh, S. (2000). Effect of Punica granatum Linn.(flowers) on blood glucose level in normal and alloxaninduced diabetic rats. Journal of Ethnopharmacology, 70(3), 309-314.

28. Mascolo, N., Capasso, F., Menghini, A., \& Fasulo, M. P. (1987). Biological screening of Italian medicinal plants for antiinflammatory activity. Phytotherapy
Research, 1(1), 28-31.

29. Gharzouli, K., Khennouf, S., Amira, S., \& Gharzouli, A. (1999). Effects of aqueous extracts from Quercus ilex 1. root bark, Punica granatum 1. fruit peel and Artemisia herba-alba Asso leaves on ethanol-induced gastric damage in rats. Phytotherapy Research, 13(1), 42-45.

30. PN, S. (1958). Evaluation of some indigenous drugs for stimulant effect on the rat uterus: a preliminary report. The Indian Journal of Medical Research,46(6), 808811.

31. Sato, A. (1990). Cancer chemotherapy with Oriental medicine (I): Antitumor activity of crude drugs with human tissue cultures in in vitro screening. Int J Orient Med,15(4), 171-183.

32. Lansky, E. P., Jiang, W., Mo, H., .. \& Campbell, M. J. (2005). Possible synergistic prostate cancer suppression by anatomically discrete pomegranate fractions. Investigational New Drugs, 23(1), 11-20.

33. Albrecht, M., Jiang, W., Kumi-Diaka, J., \& Campbell, M. J. (2004). Pomegranate extracts potently suppress proliferation, xenograft growth, and invasion of human prostate cancer cells. Journal of Medicinal Food, 7(3), 274-283.

34. Malik, A., \& Mukhtar, H. (2006). Prostate cancer prevention through pomegranate fruit. Cell Cycle (Georgetown, Tex.), 5(4), 371-373.

35. Malik, A., Afaq, F., Sarfaraz, S., ...\& Mukhtar, H. (2005). Pomegranate fruit juice for chemoprevention and chemotherapy of prostate cancer. Proceedings of the National Academy of Sciences of the United States of America, 102(41), 14813-14818.

36. Yuan, T., Ma, H., Liu, W., Niesen, D. B.,... \& Seeram, N. P. (2015). Pomegranate's neuroprotective effects against Alzheimer's disease are mediated by urolithins, its ellagitannin-gut microbial derived metabolites. ACS Chemical 